\title{
JURISPRUDENCE POSITION IN THE COMMON AND CIVIL LAWS
}

\author{
Edi Rohaedi ${ }^{1)}$ \\ ${ }^{1)}$ Universitas Pakuan, Bogor, Indonesia \\ Corresponding Author: edi.rohaedi@unpak.ac.id
}

\begin{abstract}
The development of jurisprudence continues to grow in accordance with the existing laws in the society which it is not the same as the law in legal development. It is not related to the rigid nature of the law which only regulates the general nature and the process of its formation takes a long time. In practice, the development of jurisprudence, as one of the sources of formal law, can be distinguished into two legal systems affecting the legal world. They are namely the Continental European legal system with its Civil Law System which prioritizes "codification" in the field of law and the Anglo Saxon law with its Common Law System, which is famous for the "Precedent" system binding the judges to follow the previous judgment in deciding the same case.
\end{abstract}

Keywords: legal system, jurisprudence, source of law.

\section{INTRODUCTION}

The judge in examining and adjudicating a case is not only bound by legislation alone, but can also search for legal discovery (Rechtsvinding) in solving a case that has not been clearly regulated or not regulated at all by the applicable laws and regulations. This is in accordance with the judicial function, in addition to being a law enforcer as well as legal reformer (Muchsan, [1]. Legal reform can not only be conducted by legislation alone, but it can also be done by the court with a judge's decision reflecting the existing legal developments, and where the judge's judgment is followed by other judges in deciding cases not regulated in legislation or written law.

The existence of a judge's verdict which has had a permanent legal force and is followed by other judges in deciding the case in which it is handled so it is helpful to encourage the law development . Whereas, the development of the law should be as much as possible develop in line with the development of society. Because if it is only based on legislation or written law it is certain that legal developments will slowly develop and will be far behind the dynamics of people's life change from time to time. Rationally, to overcome these problems required the existence of an unwritten source of law, in which one of them is the judge's decision in the form of jurisprudence. The development of jurisprudence continues to grow in accordance with existing laws in society is not the same as the laws that are slow in following the legal development that occurred. Since this is not related to the rigid nature of the law which only regulates the general nature and the process of its formation takes a long time.

Nevertheless, it does not mean that the existence of the law is less important as a source of formal law and even the law can provide legal certainty regarding legal acts which regulated the application of sanctions clear and assertive. However, due to the growing legal development in accordance with the development of society, not only the law is the most important source of law, but there are other formal legal sources.

\section{RESEARCH METHODS}

In addition, the development of jurisprudence as one of the sources of formal law in practice can be distinguished into two legal systems affecting the legal world, namely the Continental European legal system with its Civil Law System which prioritizes "codification" in the field of law and the Anglo-Saxon legal system with its Common Law System, where it is renowned for the "Precedent" system that binds judges to follow the judgments of the previous judges in deciding upon a common case. Nevertheless, the previous judgment of the judge may be disregarded if the earlier judgment of the judge can lead to injustices not previously considered by the judge in deciding the case.

Based on the above description, in this article, the author will describe the function and position of jurisprudence as a source of law and civil law system and common law system. Hence, the role of jurisprudence is very important in in filling the legal void and the weaknesses of the legislation in addition to anticipating the development of law that is detached in society.

\section{RESULTS AND DISCUSSION}

In the Civil Law legal system that any applicable law is basically made by the legislature. In other words, 
countries that adhere to the civil law law system prefer the "codification". This is influenced by the "French Code" where the law comes from Roman law. Therefore, the written law is more important to be used as the main source of law, while the source of the unwritten law is complementary to the legal framework of the prevailing laws and regulations. In the AngloSaxon countries, as in the United Kingdom and the United States, the most important law is "Judicial Precedent" and then follows "Legislation and ancient text books" and in limited terms is also used "Local costum" (Sudikno Mertokusumo, [2]).

In general the state that embraces this legal system prioritizes jurisprudence as its source of law, in addition to existing laws called "Act" is a complement to jurisprudence. In the British state apply "Stare decisis", namely the existence of the judge's relationship to know the judgment of the previous judge in almost the same case. Therefore, the judges' rulings are not binding on the parties alone, but also the judges (Paulus Effendie Lotulung, [3]).

Speaking of the binding of jurisprudence in the British state with its Precedent principle, the judge's verdict has a very strong binding power. According to William Geldart this stared dicisions teachings contain some ugliness and goodness, namely:

The virtues of Stare Decisis's teachings are:

" (a) the existence of legal certainty;

(b) the possibility of legal growth;

(c) the number of detailed arrangements;

(d) the practical nature of this arrangement ".

But the vices of jurisprudence are:

" (a) its strictness (rigidty)

(b) anxiety about the reasons for illogical distinctions.

(c) can cause complexity (David Barker and Colin Padfield, [4]).

The attachment of the judge to follow the judgment of the preceding judge, this may lead to the verdict not fulfilling the sense of justice, if the circumstances and conditions want to be otherwise. Therefore, the judges not only follow the judgment of the previous judges, but also must see a concrete thing in handling a case.

If each time there is a different verdict on a similar case, there will be no legal certainty of the case, while the judge is bound by the previous judge's decision, while the judge is bound by the previous judge's decision, then the judge can not follow the progress laws that occur in a society that keeps changing with the times. And later the resulting reflects on the development of the era which, in turn, it leads to injustice.

In practice, the "Stare Decisis" is not absolute, since the judge can override the previous judge's decision before the judge believes that the case indicates a difference with the previous decision (distinguishing), so that if the case is terminated the same as the previous decision, justice and violence previously unthinkable by the previous judge in the judgment (Paulus Effendie Lotulung, [3]).

Kottenhagen R.J.P. and M.C. The Kaptein [5] in his book entitled "Toegankelijkheid Van Rechtspraak" explains that in the United Kingdom the enactment of the Common Law legal system, this has led to a lack of legal qualifications, so the judge's ruling has an important meaning as a source of law. Because the judge's decision in the UK was published to be known by the public at large and in its development there were three important periods:

"1. The "de yearbook" period of 1272-1535. This includes collections of unofficial decisions by the private sector. The existence of the Precedent line at that time there were indications that the book by the Judge was considered a source of law. So this is an association of decisions made by the private sector.

2. The period of the year $1535-1865$ with the cessation of de yearbook in 1535, the occurrence of vacancies and to fill the void was filled or with the expert who made "Law Reporters, which is a legal reporting expert related to the court decision. And it is influenced by precedent practices of private records reprinted and published which are part of "The English Reports".

The period of 1865 was marked by a structured and semi-officiel way of legal reporting, self-published, so often inaccurate and complete, sometimes even different (Kottenhagen R.J.P. and Kaptein M.C., [5]).

After the previous attempts were unsuccessful, improvements were made. And in 1865 the Council of Law Reporting Opgericht was established and in 1870 the Council of Law Reporting for England and Wales, a private organization that published the judges' decisions, nevertheless the jurists regarded the Law Report as a source of law. In 1953 there was a set of court decisions in the form of Weekly law Reports and Law Reports which were based on the pre-publication of the Year Book and Weekly Law Reports [5].

Thus the existence of jurisprudence and how to publish it in the British state that embraced the Common Law law system.

The development of jurisprudence in a country that embraces a Civil Law legal system that prefers codification in the field of law, but it does not mean that jurisprudence has no important role. The State of Indonesia is one of the countries affected by the Continental European legal system with its Civil Law system.

In countries that embrace the existing Civil Law system, jurisprudence is commonly used as a filler of vacancies from lawmakers and provide legal justification to the public in seeking justice.

The development of jurisprudence can not be separated from the publication, because with the publication of the judge's decision that has become jurisprudence is expected to be known by the wider community, and not just among law only. The 
publication of jurisprudence in the state that adhere to the civil law is legalized by law and is limited to law enforcement. So the development of jurisprudence in the state of the law that the law of jurisprudence is the primary source of law in the field of law.

Among jurists there is still a different view of jurisprudence in the standard form. Therefore, the understanding in terms of redaction of jurisprudence can vary. Nevertheless some jurists have provided a definition of jurisprudence. The literal word jurisprudence comes from the Latin "jusprudentia" which means legal knowledge (rechtsgeleerdheid) and in French with the term "jurisprudence" and in Dutch with the term "jurisprudence". In the English state, jurisprudence is called the science of law and for the understanding of jurisprudence itself is called "judge made law". Thus the meaning of jurisprudence can be interpreted as a judgment of judicial bodies which is judges so that it can be called "Rechtersrecht" ( Lotulung, [3]). Subekti defines jurisprudence as judges or court rulings that are fixed and justified by the Supreme Court as the Court of Cassation or the Constitutional Court's own constitutional verdict (Constant).

\section{CONCLUSION}

In its position as a source of law, the binding force of jurisprudence to judges in the Civil Law legal system is not similar to the Common Law law system. The Common Law legal system basically implements the Precedent doctrine which means that judges are bound to previous or higher-level hierarchical judges of judgment in similar or similar cases. These decisions have binding precedent or "stare decisis" doctrines based on earlier decisions. While in the Civil Law legal system, the prevailing principle is the opposite of the precedent system, since there is essentially freedom to the judge not to feel attached to earlier decisions in similar cases.

\section{REFERENCES}

[1] Muchsan, Peradilan Administrasi Negara, Liberty, Yogyakarta, 1986

[2] Mertokusumo, Sudikno, Hukum Acara Perdata Indonesia, Liberty, Yogyakarta, 1993.

[3] Lotulung, Paulus Effendie Lotulung, Yurisprudensi Dalam Perspektif Pengembangan Hukum Administrasi Negara, Professorship Inaugural Speech at Faculty of Law Pakuan University, Bogor, 24 Nopember 1994

[4] Barker, David dan Colin Padfield, Law, Made Simple Books, 8 th Edition, Oxford, 1992.
[5] Kottenhagen R.J.P. dan Kaptein M.C., Toegankelijkheid van Rechtspraak, Gonda Quint B.V., Arnhem, 1989. 